\title{
Performance of Water in Glass Evacuated Tube Solar Water Heater under Kenya Climatic Condition
}

\author{
Ernest Kyekyere', Hiram Ndiritu², Meshack Hawi², Polline Mwambe ${ }^{1}$ \\ ${ }^{1}$ Department of Mechanical Engineering, Pan African University Institute for Basic Sciences, Technology and Innovation, Nairobi, \\ Kenya \\ ${ }^{2}$ Department of Mechanical Engineering, Jomo Kenyatta University of Agriculture and Technology, Nairobi, Kenya \\ Email: kyekyere@gmail.com
}

How to cite this paper: Kyekyere, E., Ndiritu, H., Hawi, M. and Mwambe, P. (2021) Performance of Water in Glass Evacuated Tube Solar Water Heater under Kenya Climatic Condition. Computational Water, Energy, and Environmental Engineering, 10, 37-48.

https://doi.org/10.4236/cweee.2021.102003

Received: February 19, 2021

Accepted: April 10, 2021

Published: April 13, 2021

Copyright $\odot 2021$ by author(s) and Scientific Research Publishing Inc. This work is licensed under the Creative Commons Attribution International License (CC BY 4.0).

http://creativecommons.org/licenses/by/4.0/

\begin{abstract}
Solar water heaters which provide a cost-effective and environmental friendly approach to hot water generation are in widespread application. Evacuated tube solar water heaters perform better than flat plate solar water heaters as a result of their greater surface area exposed for sunlight absorption. Water-in-glass evacuated tube solar water heaters are widely used as compared to heat-pipe solar water heaters due to their short payback periods. In this study, the performance of water-in-glass evacuated tube solar water heater is investigated through experiments under the climatic conditions in Kenya. The results revealed a daily efficiency range of $0.58-0.65$ and a daily final outlet temperature greater than $55^{\circ} \mathrm{C}$ given an initial temperature of $25^{\circ} \mathrm{C}$.
\end{abstract}

\section{Keywords}

Solar Water Heater, Water-in-Glass Evacuated Tube, Solar Collector, Solar Irradiation

\section{Introduction}

Increases in population and technological advancement have contributed to a major rise in energy demand [1]. Global demand for energy increased by $2.3 \%$ in 2018 relative to the previous year [2]. This has contributed to the existing energy crisis which is of considerable interest globally. Solar energy, which is freely available and emission-free has the capacity to meet the global energy demand. One way of utilizing solar energy is through solar water heaters (SWHs).

Solar water heaters are applied in heating of water used for industrial, house 
and other commercial applications. This is due to the use of solar collectors which absorb and convert solar radiations into thermal energy. The hot water generated is stored in insulated tanks to reduce the rate of heat loss. Solar water heaters eliminate environmental pollution resulting from the use of fossil fuels in water heating applications, reduce expenditure on fuels and electricity and also address the global energy crisis [3].

Currently, the flat plate solar water heater (FP-SWH) and the evacuated tube solar water heater (ET-SWH) are the commonly used types of solar water heater for domestic and industrial heating applications. Generally, the performance of evacuated tube solar collectors (ETSC) is better than flat plate solar collectors [4] [5]. The two commonly used evacuated tube solar water heaters are the water-in-glass system and the heat-pipe design. However, the water-in-glass evacuated tube solar water heater is used widely due to its simple design and cost effectiveness [5].

Heat-pipe evacuated tube solar water heaters consist of an evacuated tube and a heat pipe. The evacuated tube absorbs the solar radiations and converts it to thermal energy. The thermal energy is then transferred to a refrigerant inside the heat pipe. It vaporizes and rises rapidly into the condenser of the heat pipe where energy is transferred to the cold water. There is no direct connection between the refrigerant in the heat pipe and the water being heated. However, the initial cost of heat-pipe evacuated tube solar water heater is high and its payback period is long.

Water-in-glass evacuated tube solar heater consists of a set of single-ended glass tubes connected directly to a horizontally mounted storage tank. Each tube consists of an outer glass tube, which is transparent and bigger in diameter and an inner glass tube of smaller diameter. The outer surface of the inner glass tube is selectively coated for absorption of solar radiations. A vacuum is created between the outer glass tube and the inner glass tube to reduce heat losses. An insulation layer of about $50 \mathrm{~mm}$ thick is placed in between the walls of the storage tank to minimize heat loss. Water flows from the tank to the tubes where it is heated by solar radiation. The heated water rises back to the storage tank and it is replaced by cold water from the tank. Heat transfer in the system is purely by natural circulation of water [6].

Various research studies have been carried out to investigate, evaluate and predict the performance of solar water heaters under various climatic conditions. Budihardjo et al. [7] investigated the performance of evacuated tube solar collector under the climatic conditions in Australia using both experimental and numerical techniques. The results showed that evacuated tube solar heater gives $45 \%$ annual saving as compared to conventional electric heater. A study conducted by Budihardjo and Morrison [8] under the climatic condition in Sydney compared the performance of flat plate solar water heater with water in glass evacuated tube solar water heater. It was revealed that the performance of two flat plate arrays with collector area of $3.7 \mathrm{~m}^{2}$ for domestic heating was higher than 30 evacuated tube arrays with a collector area of $2.9 \mathrm{~m}^{2}$. This result can be 
attributed to the difference in collector area between the flat plate and the evacuated tube. The collector area is a key parameter in determining the quantity of solar radiation that can be absorbed.

Hayek, et al. [5] compared the performance of water-in-glass evacuated tube collector and heat-pipe evacuated tube collector according to the Eastern Mediterranean Climatic condition. The results indicated that the performance of heat-pipe evacuated tube is better than water in glass evacuated tube. However, the payback period for heat-pipe collector is long. An experimental investigation by Zhang, et al. [9] indicated that shorter evacuated tube has better thermal performance than a longer evacuated tube. Three different collector lengths were used for the study; $1600 \mathrm{~mm}, 1800 \mathrm{~mm}$ and $2100 \mathrm{~mm}$. The study indicated that the thickness of polyurethane insulation of the storage tank should be $50 \mathrm{~mm}$ thick. Critical radius of insulation, a function of the thermal conductivity of the insulation material and the external convective heat transfer coefficient is a key in insulation thickness determination. Increasing the thickness of the insulation material to a value higher than the critical radius of insulation results in an increase in the rate of heat loss.

Studies conducted by Tang, et al. [10] on evacuated tube solar collectors revealed that tilted evacuated tube collected more solar radiation than horizontally mounted evacuated tube. The positioning of the evacuated tube solar collector affects the collectible solar irradiation. Depending on the geographic location, the system must be position at an appropriate tilt angle to maximize the collectible radiation.

Various parameters including weather condition, installation tilt angle, the dimensions and number of the evacuated tubes may affect the performance of the water in glass evacuated solar water heater.

In this study, the overall performance of water in glass solar water heater under the local weather conditions in Kenya is investigated as well as the rate of heat loss from the system during the night. This will give insight into the design of improved products of water in glass evacuated tube solar water heater for the extraction of maximum heat energy from the sun.

\section{Experimental Setup}

\subsection{Description of the Experimental Setup}

An experimental setup for the study was installed at an open area where maximum absorption of solar radiation can occur. The set-up consists of 20 evacuated tubes directly connected to a storage tank of 200 litre capacity. The storage tank is made of a stainless steel inner cylinder and a plastic painted insulated galvanised external casing.

Attached to the main storage tank is a cold water header tank of capacity 8 litre. Supply of water to the system is through the cold water header tank which regulates the pressure in the system due to the limited pressure capacity of the evacuated tubes. The system operates at a maximum temperature of $200^{\circ} \mathrm{C}$ and a 
maximum pressure of 0.1 bar.

Water in glass evacuated tube solar water heaters are referred to as non-pressurised solar water heaters since it operates at very low pressure and does not require pumps to circulate the water. Evacuated tubes were inclined at an angle of 23 degrees to the horizontal. These specifications were chosen based on the common water-in-glass solar water heaters found in the Kenyan market and their installation angles. Specifications of the solar water heater are shown in Table 1.

Figure 1(a) shows the experimental set-up of the evacuated tube solar water heater and Figure 1(b) shows the inner glass tube of smaller diameter selectively coated for absorption of solar radiation within the evacuated tube.

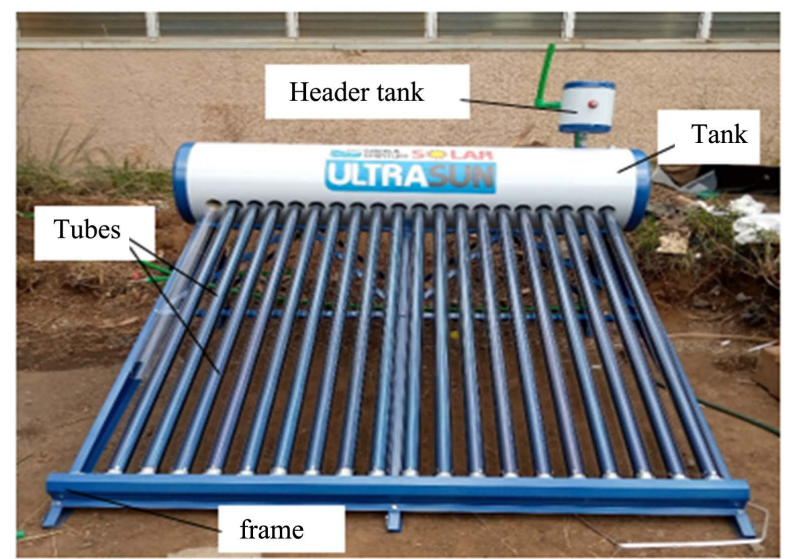

(a)

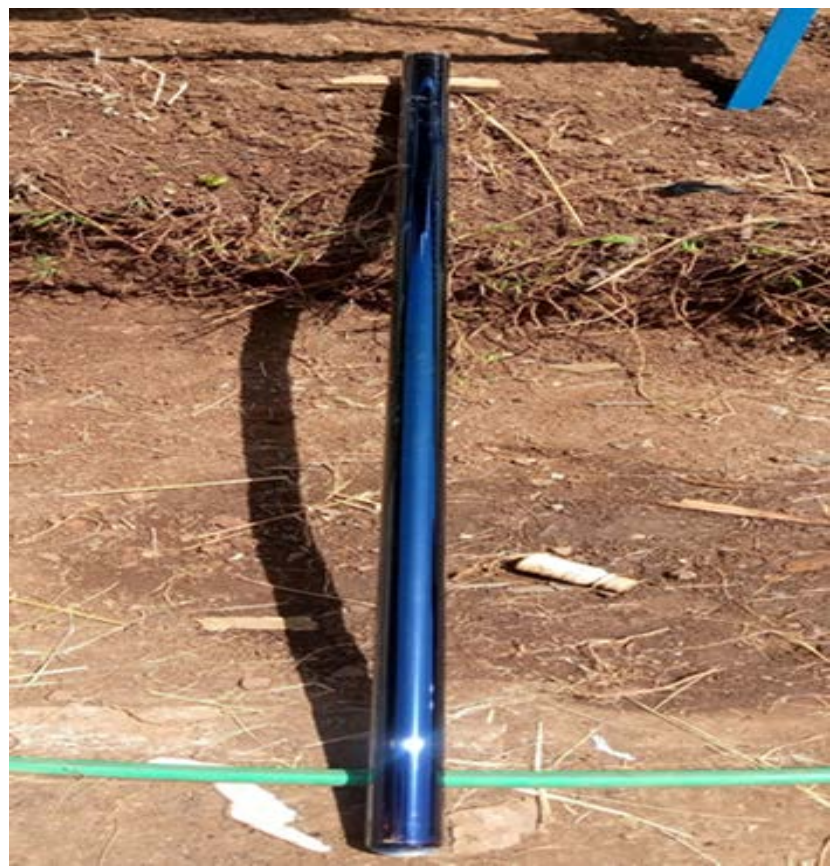

(b)

Figure 1. (a) Experimental set-up of WG-SWH and (b) coated inner glass tube responsible for solar absorption. 
Table 1. Specifications of the solar water heater.

\begin{tabular}{crc}
\hline No & Element & Specification \\
\hline 1 & Tank volume & 200 liters \\
2 & Tank outer diameter & $470 \mathrm{~mm}$ \\
3 & Tank insulation thickness & $50 \mathrm{~mm}$ \\
4 & Outer tube diameter & $58 \mathrm{~mm}$ \\
5 & Inner tube diameter & $47 \mathrm{~mm}$ \\
6 & Tube length & $1800 \mathrm{~mm}$ \\
7 & Tube tilt angle & 23 degrees \\
8 & Absorber Area & $3.28 \mathrm{~m}^{2}$ \\
\hline
\end{tabular}

\subsection{Experimental Methods}

The two common methods used for testing the performance of solar water heaters are the water draw-off and the mixing water methods [9]. However, the water draw-off method is suitable for systems which operate at very high pressures. For water in glass evacuated tube solar water heater, an appreciable volume of hot water is retained in the evacuated tubes when the draw-off method is used which could result in overestimation of the thermal performance of the system [9]. This makes the draw-off method unsuitable for performance testing of water in glass evacuated tube solar water heater.

The mixing water method was used in this study. During the study, the system was allowed to operate for 22 hours without drawing water from it. After the 22-hour period, as hot water in the system is being drained through a drain valve located at the bottom of the storage tank, cold water was fed into the system simultaneously through the header tank until a uniform temperature of $27^{\circ} \mathrm{C} \pm$ $2^{\circ} \mathrm{C}$ was obtained.

\subsection{Data Measurement}

The system was allowed to operate for 22 hours without drawing water from it. The ambient temperature, solar irradiation, wind speed and temperatures at points within the tank were measured on hourly basis starting from 9:00 am in the morning to 5:00 pm in the evening. The hot water remains in the system till 7:00 am in the next morning where the temperatures are measured to determine the amount of cooling during the night. An air vent located on the cold water header tank allows air and vapour released inside the storage tank to be discharged.

\subsection{Experimental Conditions}

The experiments were conducted in an open area within Jomo Kenyatta University of Agriculture and Technology located in Juja, Kenya. The site has latitude of -1.1833 and longitude of 37.1167 and it is mostly sunny throughout the year. The study was conducted in the months of January and February. 
The surrounding air temperatures ranged from $21^{\circ} \mathrm{C}$ to $32^{\circ} \mathrm{C}$ with an average ambient temperature of about $28^{\circ} \mathrm{C}$. The speed of wind in the surrounding ranged from $0.5 \mathrm{~m} / \mathrm{s}$ to $4 \mathrm{~m} / \mathrm{s}$ with an average wind speed of $2.4 \mathrm{~m} / \mathrm{s}$ and the solar irradiation in the area ranged from $0 \mathrm{~W} / \mathrm{m}^{2}$ to $1100 \mathrm{~W} / \mathrm{m}^{2}$.

\subsection{Instrumentation}

Solar irradiation was measured using solar power meter TM-206, the temperature readings in the tank were taken using digital thermometer type $\mathrm{K}(\mathrm{CA})$, weather station temperature and humidity sensor was used to measure atmospheric temperature while the speed of the wind was measured using Anemometer. Table 2 shows specifications of the devices used for the data collection.

\section{Theoretical Analysis}

The analysis of the performance of water-in-glass solar water heater involves exposing the evacuated tubes to solar radiations and measuring the initial temperature of water in the storage tank and the final temperature of water in the tank. Heat gained by the system was obtained as

$$
Q=m c_{p w}\left(T_{\text {out }}-T_{\text {in }}\right)
$$

where $Q$ is the daily heat gain $\left(\mathrm{MJ} / \mathrm{m}^{2}\right), m$ is the mass of water in the tank $(\mathrm{kg})$, $c_{p w}$ is specific heat of water at constant pressure $\left(\mathrm{kJ} /\left(\mathrm{kg}{ }^{\circ} \mathrm{C}\right)\right), T_{i n}$ is the initial temperature of water in the tank $\left({ }^{\circ} \mathrm{C}\right)$ and $T_{\text {out }}$ temperature of water at the tank outlet $\left({ }^{\circ} \mathrm{C}\right)$.

The efficiency of the system can be determined by dividing the power output (heat gained) by the power input. For solar water heaters, the source of energy into the system is solar energy. Solar irradiation, G, received and absorbed by the tubes is the power input. This energy is then transferred to the water in the tubes. A natural circulation heat transfer mechanism occurs which heats the water in the storage tank. The efficiency of the system which is generally referred to as instantaneous efficiency is calculated using:

$$
\eta=\frac{m c_{p w}\left(T_{\text {out }}-T_{\text {in }}\right)}{A_{c} G}
$$

where $\eta$ is the efficiency of solar water heater, $A_{c}$ is the surface area of collector $\left(\mathrm{m}^{2}\right), G$ is the solar irradiation $\left(\mathrm{MJ} / \mathrm{m}^{2}\right)$.

The equation can be written in terms of density and the ratio of solar water tank volume to collector area [9], as

Table 2. Specification of the measuring devices.

\begin{tabular}{cccc}
\hline Parameter & Instrument & Range of measurement & Precision \\
\hline Solar irradiation & Solar power meter TM-206 & $0-200 \mathrm{~W} / \mathrm{m}^{2}$ & $\pm 10 \mathrm{~W} / \mathrm{m}^{2}$ \\
Temperature in tank & Thermometer type K (CA) & $-65^{\circ} \mathrm{C}$ to $1000^{\circ} \mathrm{C}$ & $\pm 1^{\circ} \mathrm{C}$ \\
Surrounding wind speed & Anemometer & $0-20 \mathrm{~m} / \mathrm{s}$ & $\pm 0.3 \mathrm{~m} / \mathrm{s}$ \\
\hline
\end{tabular}




$$
\eta=\frac{\rho_{w} R_{V A} C_{p w}\left(T_{\text {out }}-T_{\text {in }}\right)}{G}
$$

where $R_{V A}$ is the ratio of the storage tank volume to the area of the collector in $\mathrm{L} / \mathrm{m}^{2}$ and $\rho_{w}$ is the density of water $\left(\mathrm{kg} / \mathrm{m}^{3}\right)$.

\section{Results and Discussion}

\subsection{Temperature Distribution in the Tank}

Daily measurements were taken from 9:00 am to 5:00 pm. Temperatures at different points in the tank as shown in Figure 2 were measured.

Where $\mathrm{Tu}$ is the temperature at topmost part of the storage tank, Tm is the temperature at the middle, $\mathrm{Tb}$ temperature at bottom of tank. Figure 3 shows the ambient temperatures and solar irradiation measured on $28^{\text {th }}$ January. The solar irradiation increased in the morning until 1:00pm where a maximum irradiation was recorded and then a gradual reduction in the irradiation was seen until $6 \mathrm{pm}$ in the evening. The maximum ambient temperature recorded during the day was $31^{\circ} \mathrm{C}$.

Figure 4 shows the temperature distribution of water at the bottom, middle and top of the tank at various hours of the day for two different days. Variations in temperature were observed at different points in the tank. The deviation in temperatures between the middle portion and the top of the tank is negligible. However, a major deviation in temperature is seen between the middle portion of the tank and the bottom of the tank.

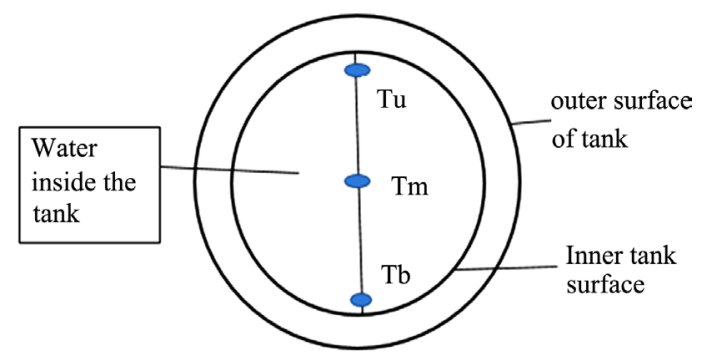

Figure 2. Points of temperature measurement in the storage tank.

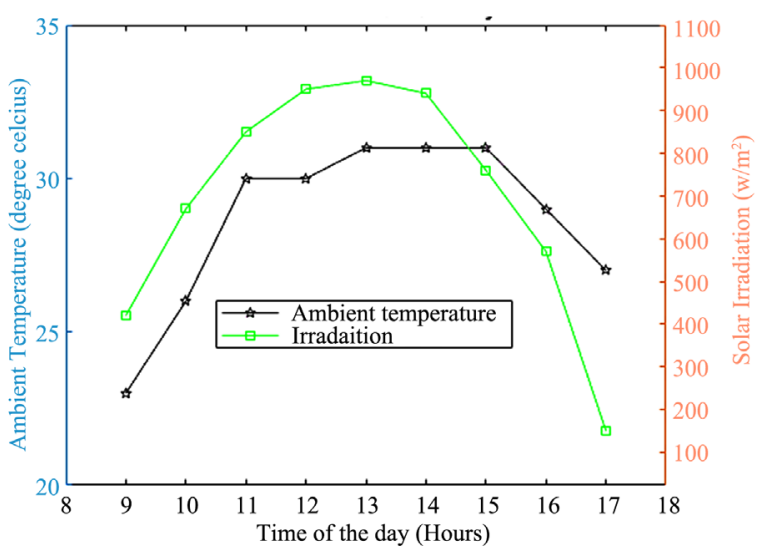

Figure 3. Typical ambient temperature and irradiation measured on 28th January. 


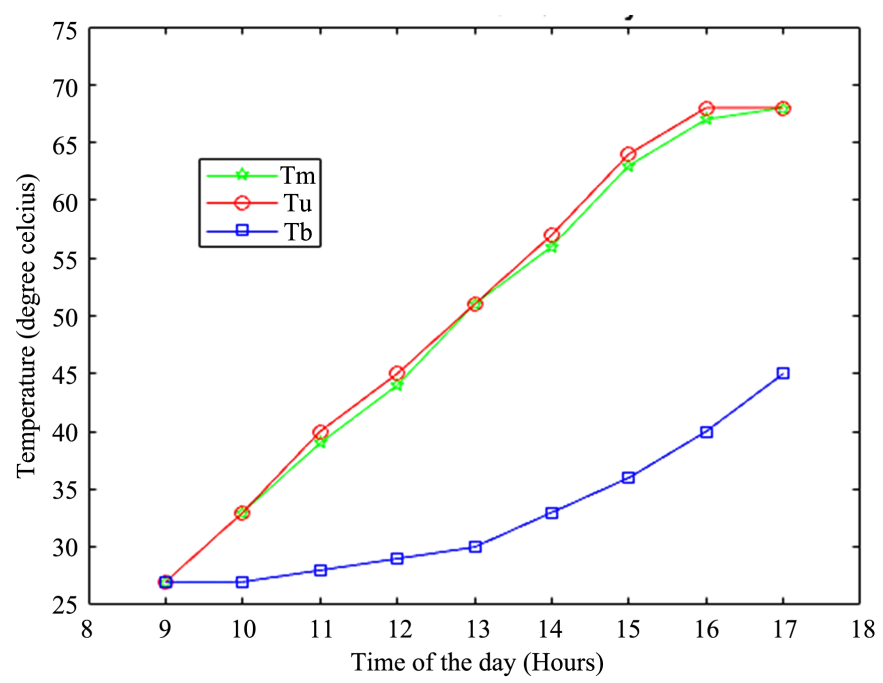

(a)

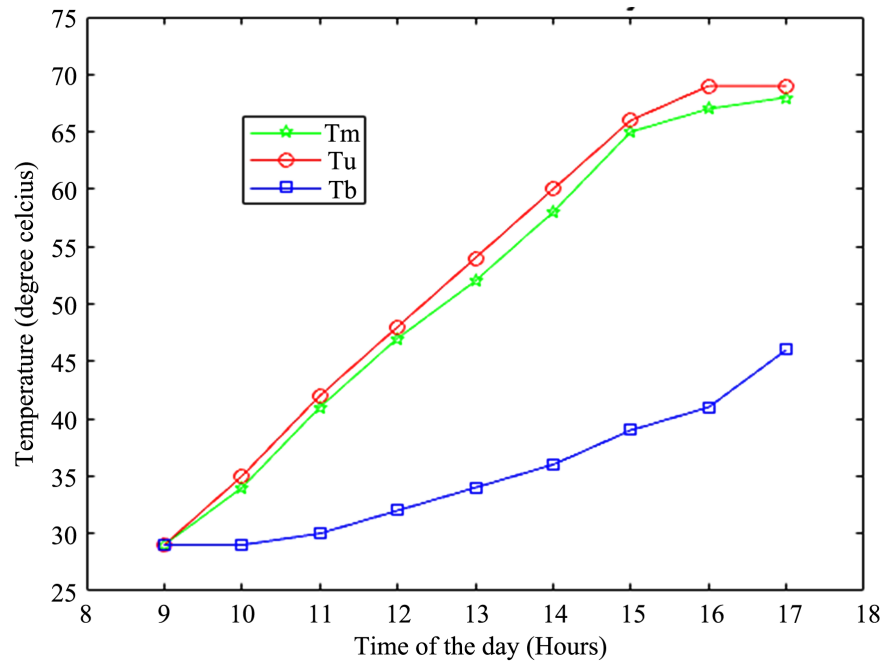

(b)

Figure 4. Temperature distribution at various point in the tank during various hours of the day, (a) $28^{\text {th }}$ January, 2021; (b) $29^{\text {th }}$ January, 2021 (Tu is the temperature of water at the top of the tank, Tm is the temperature at the middle of the tank and Tb is the temperature at the bottom of the tank as seen in Figure 2).

This is as a result of the fluid transfer between the evacuated tubes and the tank [11]. The evacuated tubes are inclined at an angle to the tank and hence leave a portion of the water in the tank below the tubes thermally inactive. Since the hot water returning from the tubes is less dense compared to the cold water below the tubes in the tank, penetration of hot water to the bottom of tank through natural circulation is hindered which leads to low water temperature at the bottom of the tank. This reduces the fraction of hot water in the tank available for use at any point in time. These results agree with the work done by Morrison, et al. [11], Tang et al. [12] and Bracamonte, et al. [13]. The fraction of hot water within the tank can be increased sufficiently by increasing the tilt angle of the tubes and reducing the length of the tubes inside the tank. 


\subsection{Rate of Cooling in the Night}

The hot water in the tank is retained throughout the night until the next morning. Temperatures at the top, middle portion and the bottom of the tank were recorded in the morning at 7:00am to determine the rate of heat loss from the tank during the night. A uniform temperature was recorded at the middle and at the upper portions of the tank for the various days while the temperature of water at the bottom remained lower than at the portions above the opening of the tube. Table 3 shows the temperature distribution in tank at 9:00am, 5:00pm in the evening and 7:00am in the morning of the following day.

The temperature distribution shows a decrease in temperature of water at the portion above the tube opening in the tank and a rise in temperature of water at the bottom of the tank during the morning hours as seen in Table 3 and Figure 5. This observation can be attributed to the natural convection heat transfer that occurs between the hot water at the top of the tank and the cold water at the bottom of the tank.

This phenomenon tends to establish a uniform temperature in the tank in the absence of solar radiations in the night. Mixing of the hot water above the tube opening in tank with the cold water below the tube opening occurs which leads to a decrease in temperature at the upper part of the tank. Heat transfer between the solar water heater and the ambient is minimum during the night.

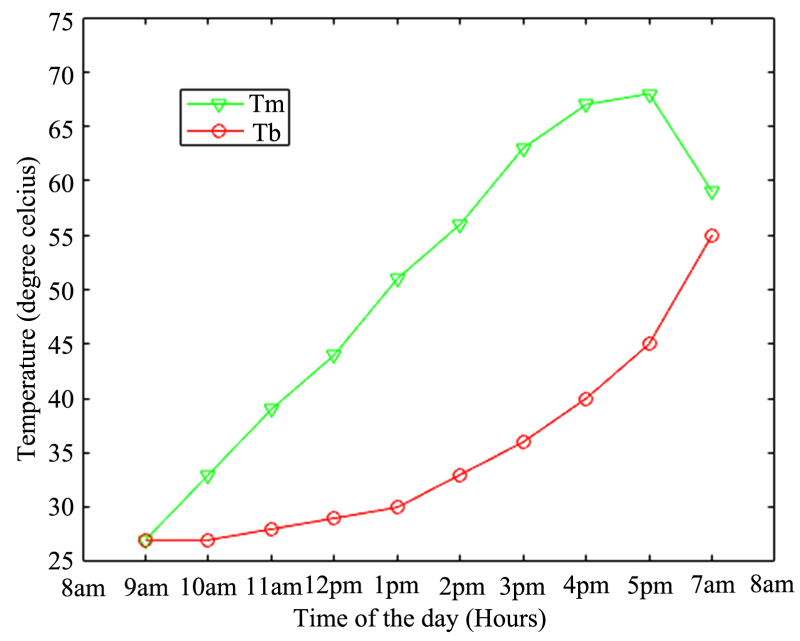

Figure 5. Temperature distribution at the upper part of the storage tank and at the bottom of the tank on $28^{\text {th }}$ January.

Table 3. Temperature distribution in the tank during the evening and the next morning.

\begin{tabular}{|c|c|c|c|c|c|c|}
\hline \multirow[t]{2}{*}{ Date } & \multicolumn{2}{|c|}{$\begin{array}{l}\text { Initial temperatures } \\
\qquad(9: 00 \mathrm{am})\end{array}$} & \multicolumn{2}{|c|}{$\begin{array}{l}\text { Evening } \\
(5: 00 \mathrm{pm})\end{array}$} & \multicolumn{2}{|c|}{$\begin{array}{l}\text { Morning (7:00am) } \\
\text { of the following day }\end{array}$} \\
\hline & $\mathrm{Tm} /{ }^{\circ} \mathrm{C}$ & $\mathrm{Tb} /{ }^{\circ} \mathrm{C}$ & $\mathrm{Tm} /{ }^{\circ} \mathrm{C}$ & $\mathrm{Tb} /{ }^{\circ} \mathrm{C}$ & $\mathrm{Tm} /{ }^{\circ} \mathrm{C}$ & $\mathrm{Tb} /{ }^{\circ} \mathrm{C}$ \\
\hline $26^{\text {th }}$ January, 2021 & 28 & 28 & 64 & 42 & 55 & 52 \\
\hline $28^{\text {th }}$ January, 2021 & 27 & 27 & 68 & 45 & 59 & 55 \\
\hline $29^{\text {th }}$ January, 2021 & 29 & 29 & 69 & 46 & 60 & 55 \\
\hline
\end{tabular}




\subsection{Performance of Water in Glass Evacuated Tube Solar Water Heater}

The performance of water in glass evacuated tube solar water heater was investigated using 20 tubes connected directly to a 200 litre tank. Each tube has a volume of 2.5 litres. The total volume of the 20 tubes is 50 litres. The system is filled with water in the morning and allowed to operate until $5 \mathrm{pm}$ in the evening without drawing water from it. The initial temperature in the morning is recorded as Tin and the final temperature in the evening is measured as Tout. Corresponding irradiation levels are measured to determine the efficiency of the system. Table 4 shows the daily irradiation, the daily heat gain, the average atmospheric temperature (Ta) and daily thermal efficiency of the system for four different days. Figure 6 shows the daily performance of the system.

The amount of daily incident irradiation has a great influence on the final temperature of the system. Heat gained by the water in the tank is relatively high for higher solar irradiations. Therefore, placing the solar water heater at a point of maximum solar irradiation incidence is beneficial for optimum heat gain. However, the thermal efficiency of system is not proportional to the daily solar irradiation received. The efficiency of water in glass evacuated tube solar water

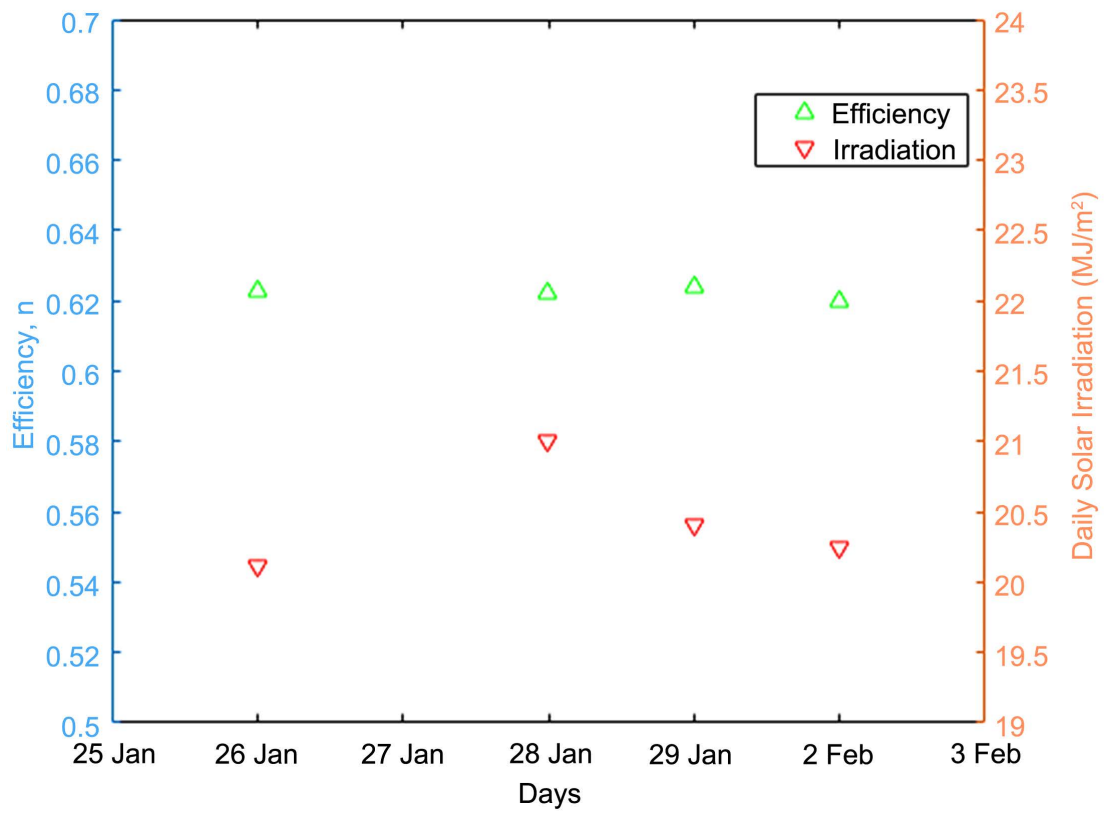

Figure 6. Performance of water in glass evacuated tube solar water heater.

Table 4. Performance of water in glass evacuated tube solar water heater.

\begin{tabular}{ccccccc}
\hline Day & $\mathrm{G}\left(\mathrm{MJ} / \mathrm{m}^{2}\right)$ & $\mathrm{Q}(\mathrm{MJ})$ & $\mathrm{T}_{\mathrm{a}}\left({ }^{\circ} \mathrm{C}\right)$ & $\mathrm{T}_{\text {in }}\left({ }^{\circ} \mathrm{C}\right)$ & $\mathrm{T}_{\text {out }}\left({ }^{\circ} \mathrm{C}\right)$ & $\mathrm{n}_{\mathrm{d}}$ \\
\hline $26^{\text {th }}$ January 2021 & 20.12 & 37.62 & 27.4 & 28 & 64 & 0.623 \\
$28^{\text {th }}$ January 2021 & 21.00 & 42.85 & 28.6 & 27 & 68 & 0.622 \\
$29^{\text {th }}$ January 2021 & 20.41 & 41.80 & 28.7 & 29 & 69 & 0.624 \\
$2^{\text {nd }}$ February 2021 & 20.24 & 37.60 & 29.0 & 28 & 64 & 0.620 \\
\hline
\end{tabular}


heater was found to be around 0.58 - 0.65 under the climatic conditions of Kenya.

\section{Conclusions}

Experimental investigation of the performance of water in glass evacuated tube solar water heater was conducted under the climatic conditions in Kenya. Daily measurements were taken throughout the day to determine the output temperature, heat gain and the daily efficiency of the system.

Results show a minimum heat transfer between the solar water heater and the ambient during the night. Reduction in the outlet temperature in the morning is significantly influenced by the mixing of the hot water above the tube opening and the cold water below during the night.

The final temperatures at the outlet of the solar water heater were above $55^{\circ} \mathrm{C}$ given an initial temperature of $25^{\circ} \mathrm{C}$ for a whole day heat collection with a daily system efficiency range of $0.58-0.65$.

\section{Acknowledgements}

The authors are sincerely grateful to the Pan African University Institute for Basic Sciences, Technology and Innovation for the financial support and also to Muigai Joseph of the Thermodynamics Lab of JKUAT for his support in the experimental setup.

\section{Conflicts of Interest}

The authors declare no conflicts of interest regarding the publication of this paper.

\section{References}

[1] Kannan, N. and Vakeesan, D. (2016) Solar Energy for Future World: - A review. Renewable and Sustainable Energy Reviews, 62, 1092-1105.

https://doi.org/10.1016/j.rser.2016.05.022

[2] REN21 (2019) Renewables 2019 Global Status Report. REN21 Secretariat, Paris.

[3] Kalogirou, S.A. (2004) Environmental Benefits of Domestic Solar Energy Systems. Energy Conversion and Management, 45, 3075-3092. https://doi.org/10.1016/j.enconman.2003.12.019

[4] Budihardjo, I., Morrison, G.L. and Behnia, M. (2007) Natural Circulation Flow through Water-in-Glass Evacuated Tube Solar Collectors. Solar Energy, 81, 1460-1472. https://doi.org/10.1016/j.solener.2007.03.002

[5] Hayek, M., Assaf, J. and Lteif, W. (2011) Experimental Investigation of the Performance of Evacuated-Tube Solar Collectors under Eastern Mediterranean Climatic Conditions. Energy Procedia, 6, 618-626. https://doi.org/10.1016/j.egypro.2011.05.071

[6] Morrison, G.L., Budihardjo, I. and Behnia, M. (2005) Measurement and Simulation of Flow Rate in a Water-in-Glass Evacuated Tube Solar Water Heater. Solar Energy, 78, 257-267. https://doi.org/10.1016/j.solener.2004.09.005

[7] Budihardjo, I., Morrison, G.L. and Behnia, M. (2003) Development of TRNSYS 
Models for Predicting the Performance of Water-in-Glass Evacuated Tube Solar Water Heaters in Australia. School of Mechanical \& Manufacturing Engineering, $1-10$.

[8] Budihardjo, I. and Morrison, G.L. (2009) Performance of Water-in-Glass Evacuated Tube Solar Water Heaters. Solar Energy, 83, 49-56.

https://doi.org/10.1016/j.solener.2008.06.010

[9] Zhang, X., You, S., Xu, W., Wang, M., He, T. and Zheng, X. (2014) Experimental Investigation of the Higher Coefficient of Thermal Performance for Water-in-Glass Evacuated Tube Solar Water Heaters in China. Energy Conversion and Management, 78, 386-392. https://doi.org/10.1016/j.enconman.2013.10.070

[10] Tang, R., Gao, W., Yu, Y. and Chen, H. (2009) Optimal Tilt-Angles of All-Glass Evacuated Tube Solar Collectors. Energy, 34, 1387-1395.

https://doi.org/10.1016/j.energy.2009.06.014

[11] Morrison, G.L., Budihardjo, I. and Behnia, M. (2004) Water-in-Glass Evacuated Tube Solar Water Heaters. Solar Energy, 76, 135-140. https://doi.org/10.1016/j.solener.2003.07.024

[12] Tang, R., Yang, Y. and Gao, W. (2011) Comparative Studies on Thermal Performance of Water-in-Glass Evacuated Tube Solar Water Heaters with Different Collector Tilt-Angles. Solar Energy, 85, 1381-1389. https://doi.org/10.1016/j.solener.2011.03.019

[13] Bracamonte, J., Parada, J., Dimas, J. and Baritto, M. (2015) Effect of the Collector Tilt Angle on Thermal Efficiency and Stratification of Passive Water in Glass Evacuated Tube Solar Water Heater. Applied Energy, 155, 648-659.

https://doi.org/10.1016/j.apenergy.2015.06.008 